\title{
Lektorok, 2018
}

\section{Reviewers, 2018}

2018-ban 91 lektorral dolgoztunk együtt, akik szakértelmükkel segítették a szerkesztőséget és a szerzőket abban, hogy a Tér és Társadalomban színvonalas tanulmányok jelenhessenek meg. Ezúton is köszönjük munkájukat! 2018-ban lektoraink voltak:

$\begin{array}{lll}\text { A. Gergely András } & \text { Grünhut Zoltán } & \text { Nagy Gyula } \\ \text { Bajmócy Péter } & \text { Győri Róbert } & \text { Nagy Ildikó Réka } \\ \text { Balogh Péter } & \text { Gyuris Ferenc } & \text { Nemes Nagy József } \\ \text { Barancsi Ágnes } & \text { Hajdú Zoltán } & \text { Ongjerth Richárd } \\ \text { Barta Györgyi } & \text { Hakszer Richárd } & \text { Perger Éva } \\ \text { Berki Márton } & \text { Hardi Tamás } & \text { Póla Péter } \\ \text { Bernek Ágnes } & \text { Horváth Áron } & \text { Pődör Andrea } \\ \text { Bottlik Zsolt } & \text { Horváth M. Tamás } & \text { Rechnitzer János } \\ \text { Burger Csaba } & \text { Horváth Vera } & \text { Ricz Judit } \\ \text { Buzás Norbert } & \text { Irimiás Anna } & \text { Ságvári Bence } \\ \text { Czirfusz Márton } & \text { Jankó Ferenc } & \text { Sikos T. Tamás } \\ \text { Csatári Bálint } & \text { Jelinek Csaba } & \text { Somlyódyné Pfeil Edit } \\ \text { Cseke László } & \text { Kerekes Sándor } & \text { Stepper Péter } \\ \text { Dabasi-Halász Zsuzsanna } & \text { Kiss Edit Éva } & \text { Szabó Balázs } \\ \text { Dávid Lóránt } & \text { Koós Bálint } & \text { Szabó Béla } \\ \text { Deák András György } & \text { Kozma Miklós } & \text { Szabó Julianna } \\ \text { Dreisziger Nándor } & \text { Kozma Tamás } & \text { Szabó Pál } \\ \text { Dusek Tamás } & \text { Körösi István } & \text { Szalavetz Andrea } \\ \text { Egedy Tamás } & \text { Kőszeghy Lea } & \text { Szaló Péter } \\ \text { Egyed Ildikó } & \text { Kukely György } & \text { Szemerey Samu } \\ \text { Elekes Zoltán } & \text { Lennert József } & \text { SzörényinéKukorelliIrén } \\ \text { Fábián Attila } & \text { Losoncz Miklós } & \text { Tagai Gergely } \\ \text { Faragó László } & \text { Lukovics Miklós } & \text { Tátrai Patrik } \\ \text { Farkas György } & \text { Lux Gábor } & \text { Timár Judit } \\ \text { Finta István } & \text { Meszmann T. Tibor } & \text { Tóth Balázs István } \\ \text { Fleischer Tamás } & \text { Mezei Cecília } & \text { Trócsányi András } \\ \text { Forray Katalin } & \text { Michalkó Gábor } & \text { Váradi Monika Mária } \\ \text { Gál Zoltán } & \text { Molnár Ernó } & \text { Varga Attila } \\ \text { Gébert Judit } & \text { Móricz Péter } & \text { Velkey Gábor } \\ \text { Gonda Tibor } & \text { Nagy Erika } & \\ \text { Gordos Tamás } & \text { Nagy Gábor } & \\ & & \end{array}$

